\title{
First description of the micro-habitat selection pattern of the island endemic Juan Fernandez Tit-tyrant
}

\section{Primera descripción del patrón de selección de micro-hábitat del Cachudito de Juan Fernández}

\author{
Gerardo E Soto ${ }^{1, *}$, Pablo M Vergara ${ }^{1}$, Ingo J Hahn ${ }^{3}$, Christian G Pérez-Hernández ${ }^{1}$, Marlene E \\ LIZAMA $^{1}$, Julia BAUMEISTER ${ }^{3}$ \& JAIME PIZARRO ${ }^{2}$ \\ 'Departamento de Gestión Agraria, Universidad de Santiago de Chile, Alameda Libertador Bernardo O'Higgins 3363, Estación \\ Central, Santiago, Región Metropolitana, Chile. \\ ${ }^{2}$ Departamento de Ingeniería Geográfica, Universidad de Santiago de Chile, Alameda Libertador Bernardo O’Higgins 3363, \\ Estación Central, Santiago, Región Metropolitana, Chile. \\ ${ }^{3}$ Institute of Landscape Ecology, University of Münster, Robert-Koch-Str. 28, D-48149 Münster, Germany \\ "E-mail: gerardo.soto@usach.cl
}

\begin{abstract}
RESUMEN
Para las aves que son endémicas de islas oceánicas el nivel de especialización en el uso del hábitat puede ser un factor importante de considerar en el incremento del riesgo de extinción de estas especies. En este estudio, usamos datos de redes de niebla y radiotelemetría para determinar el patrón de uso de micro-hábitat por el Cachudito de Juan Fernández (Anairetes fernandezianus), una especie de ave endémica del archipiélago de Juan Fernández (Chile). El individuo seguido por radiotelemetría estableció su ámbito de hogar exclusivamente en áreas centrales del bosque nativo residual. Los modelos regresivos de abundancia y las Funciones de Utilización de Recursos mostraron fuertes preferencias de micro-hábitat por los cachuditos. Los valores de abundancia y utilización de recurso por los cachuditos decrecieron con la distancia al matorral exótico y aumentaron con la distancia a los claros hechos por humanos dentro bosque. La heterogeneidad natural en las condiciones del micro-hábitat también afectan el patrón de selección de micro-hábitat, con probabilidades de uso y abundancia aumentando en las proximidades de lugares húmedos dominados por Gunnera peltata. Estos hallazgos demuestran que los cachuditos no usan el bosque nativo al azar. Por lo tanto, la conservación de esta población de cachuditos, que ha experimentado una fuerte declinación en las ultimas décadas, puede ser mejorada incorporando estas preferencias de micro-hábitat en los programas de manejo.
\end{abstract}

Palabras clave: Isla Robinson Crusoe, Anairetes fernandezianus, Micro-hábitat.

\begin{abstract}
The level of specialization of endemic island birds to their native habitats could contribute importantly to increase their extinction risk. We used abundance obtained from mist-netting and radio telemetry data from one individual to determine the micro-habitat use pattern of Juan Fernandez Tit-tyrants (Anairetes fernandezianus) within native forest. The tracked male tit-tyrant established its home range exclusively in core native forest areas. Regression models of abundance and Resource Utilization Functions showed strong micro-habitat preferences of tit-tyrants. The abundance and utilization probabilities of tit-tyrants declined with distance to exotic shrub and increased with distance to human created gaps. Natural heterogeneity in micro-habitat conditions also affected the micro-habitat selection pattern, with use probabilities and abundance increasing with proximity to the humid sites dominated by Gunnera peltata. These findings demonstrate that tit-tyrants do not use native forest sites at random. Therefore, the conservation and recovery of the declining tit-tyrant population could be improved by incorporating such micro-habitat preferences in habitat management programs.
\end{abstract}

KEYwords: Robinson Crusoe Island, Anairetes fernandezianus, micro-habitat.

\section{INTRODUCTION}

Bird species endemic to oceanic islands tend to be highly vulnerable to habitat loss and degradation (Owens \& Bennett 2000; Fordham and Brook 2010). Because their populations have natural small sizes and have been exposed to a long-term historical isolation, bird species endemic to oceanic islands tend to have higher extinction rates than their mainland relatives (Loehle and Eschenbach 2012). In addition, the level of specialization of endemic island 
birds to native habitats which are being lost and disturbed by humans could contribute importantly to increase their extinction risk (Hahn et al. 2011a, Cofré 1999).

The Juan Fernandez Tit-tyrant Anairetes fernandezianus is a small insectivorous species endemic to Robinson Crusoe Island and considered as near threatened (IUCN 2011). Previous studies suggest that this tit-tyrant species prefers to use native forests instead of human-associated habitats with their nests being located in the native canopy (Hahn et al. 2005, 2006, 2011a, 2011b). The loss and degradation of native forest by human activities and introduced herbivores currently represents the major conservation problem for species endemic to Robinson Crusoe like tit-tyrants (Cuevas and van Leersum 2001; Ricci 2006). This habitat loss has contributed to the reduction of the population size of the tit-tyrant, which has experienced a significant decline of about 63 percent during the last 15 years (Hahn et al. 2011a).

Understanding how birds select and use their habitats may be considered as a primary step for planning and management of conservation areas like Robinson Crusoe Island, which has been declared National Park since 1935 and an UNESCO Biosphere Reserve since 1977. However, habitat selection is a scale-dependent process resulting from spatial variation in how birds perceive habitat features and the spatial distribution of habitat components (Kristan 2006; Vergara \& Armesto 2009). This implies that the ecological responses of tit-tyrants to micro-habitat structures and environmental gradients within the native forest vegetation may be crucial for planning conservation activities for this small tit-tyrant population.

In this study, we aim to report the first home range estimate of a Juan Fernandez Tit-tyrant and assess the micro-habitat use pattern of this species. Although coarse scale habitat selection has been described for the Juan Fernandez Tittyrant (e.g., Roy et al. 1999; Hahn 2006; Hahn et al. 2005, 2006, 2011a, 2011b), their micro-habitat preferences within the native forest still remain unknown. The native island forest is naturally heterogeneous and surrounded mainly by dense shrub formations of exotic species which have invaded areas where native forest was cut (Hahn et al. 2010). The unsuitable conditions in the exotic shrub matrix may spread into the forest, thus affecting the habitat selection pattern of tit-tyrants. In addition, the presence of forest gaps created by the elimination of invasive plants within the forest, could have further consequences on the habitat use pattern of tittyrants.

\section{Methods}

\section{Study Site}

Robinson Crusoe Island $\left(47.1 \mathrm{~km}^{2}\right)$ is located ca. 600 $\mathrm{km}$ off the Chilean coast in the South-east Pacific Ocean $\left(33^{\circ} 33^{\prime} 38^{\prime \prime} \mathrm{S}\right.$ and $\left.78^{\circ} 56^{\prime} 44^{\prime \prime} \mathrm{W}\right)$. It was once largely covered by native forest but since the European discovery in the year 1574 habitats have been extensively degraded and lost (Skottsberg 1956; Stuessy and Ono 1998). These accumulated disturbances have resulted in a variety of different human-induced habitats for native bird species such as lowland scrub (290 ha), ridge scrub (599 ha), settlement area (109 ha) and non-native grassland (2,946 ha), reducing native forest to less than $25 \%$ (i.e., 990 ha) of their original size (Hahn et al. 2005). Of these habitats, Juan Fernandez Tit-tyrants tend to select for native forest while marginally using exotic scrub, ridge scrub and settlement areas (Hahn et al. 2011a). The structure and composition of native forest, however, is naturally heterogeneous due to the variation in topography, exposure and proximity of watersheds (Hahn et al. 2010).

Our study area (10 ha) was located in the "Plazoleta del Yunque", a relatively flat site appropriate to carry out telemetry studies (Fig. 1). Vegetation and micro-habitat features of the study area were classified on the basis of geo-referenced habitat plots and high-resolution Google Earth imagery. We quantified two types of micro-habitat variables which could be important in explaining the microhabitat use pattern of tit-tyrants, including: i) Compositebased variables, which characterize the micro-habitat used directly by the animal; ii) Distance-based variables, defined as the Euclidean distance from animal locations to habitat features (e.g., Aebischer et al. 1993; Conner et al. 2003).

In order to estimate micro-habitat features, vegetation of the study site was spatially classified as: 1) Gunnera shrub, defined as sites dominated by Gunnera peltata, an endemic large-leaved plant. Gunnera shrubs occur in the moister areas, including steep slopes sites as well as along watersheds, being occasionally mixed with Robinsonia spp. and Juania australis. 2) Native forest dominated by trees such as Myrcengenia fernandeziana, Drimys confertifolia and Fagara mayu. In native forest, tit-tyrant nests are usually located in Myrceugenia trees. 3) Forest gaps ranging between 0.01 and 0.7 ha in size, which were artificially generated to eliminate exotic shrub patches in core areas of the native forest remnants by a Chilean government agency (CONAF; see Fig. 2). Consequently, forest gaps lack vegetation cover but most of the ground is covered by branches from cut shrubs. 4) Exotic shrub formations composed by a mix of Aristotelia chilensis, Rubus ulmifolius and Ugni molinae. 


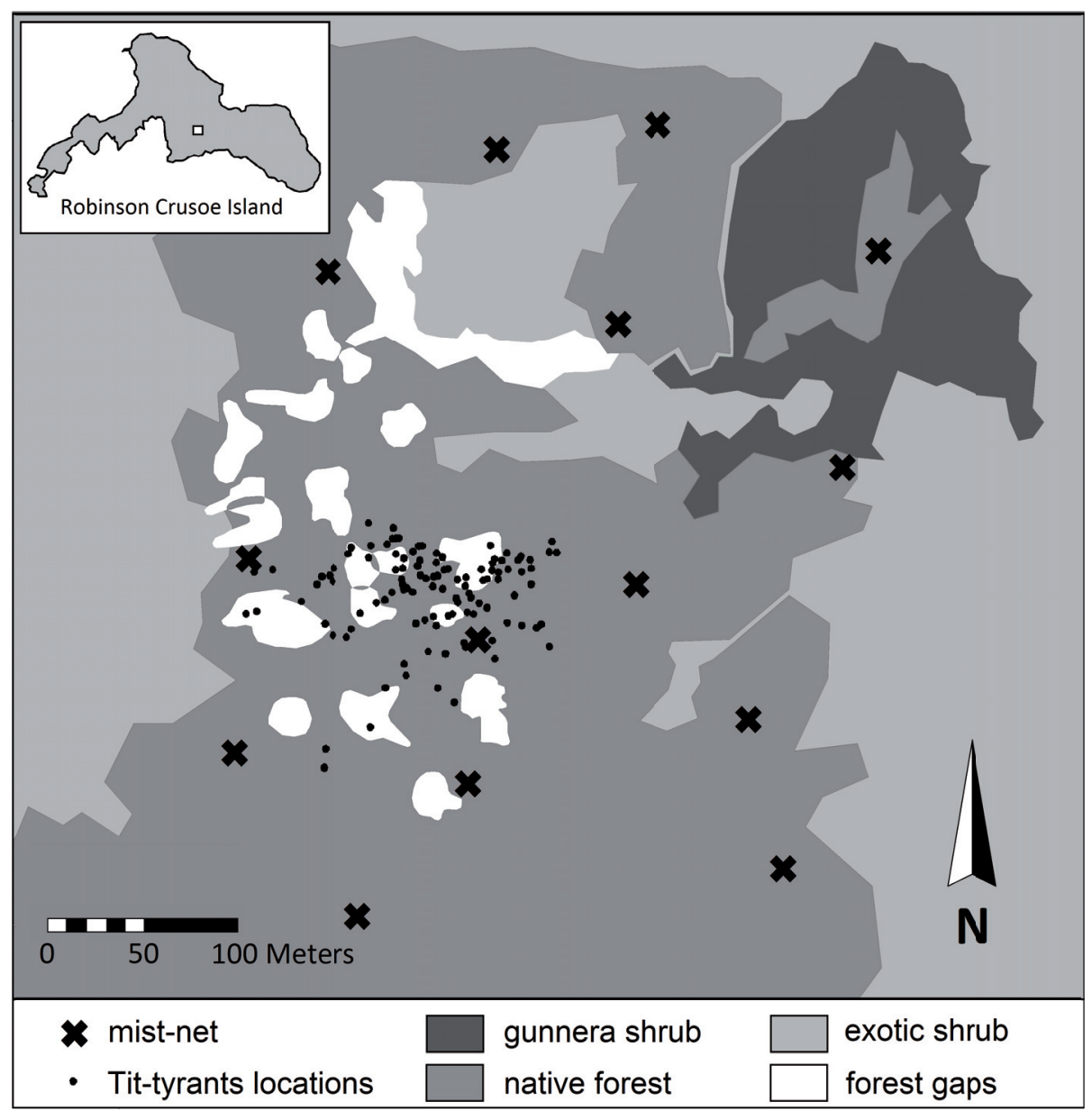

FIGURE 1. Map of the study site showing the main habitat types in Robinson Crusoe Island including telemetry fixes (estimated locations) of the sampled tit-tyrant and mist-nets used for validating kernel estimates (see text).

Figura 1. Mapa del sitio de estudio que muestra los principales tipos de hábitat en la isla Robinson Crusoe incluyendo los puntos de telemetría (localizaciones estimadas) del Cachudito muestreado y de las redes de niebla usadas para validar las estimaciones del kernel.

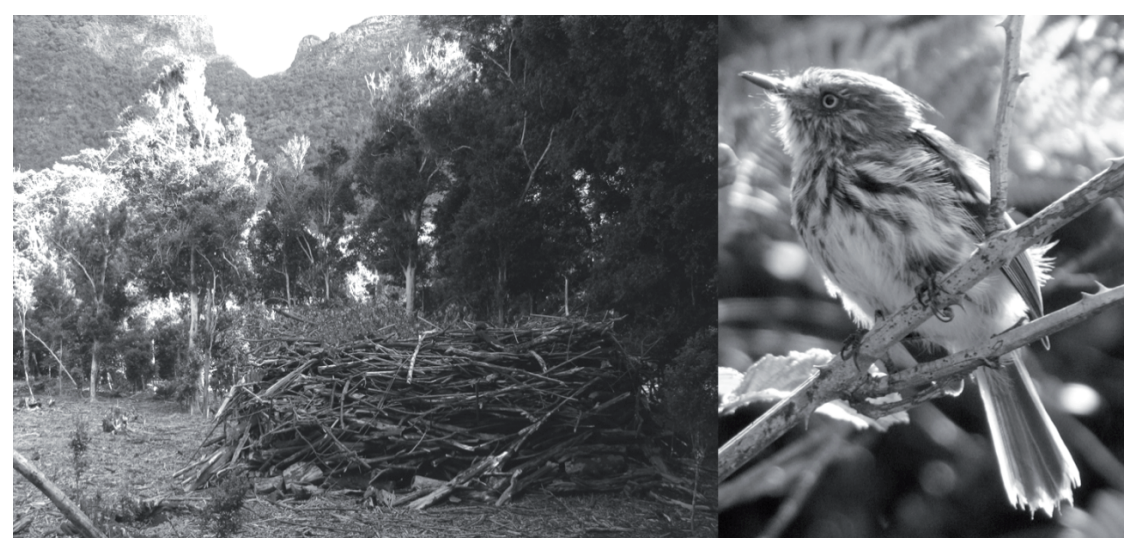

FIGURE 2. (Left) Details of a human-caused forest gap including cut branches accumulated on the ground and the adjacent forest edge, Plazoleta de Yunque (photo credit: Gerardo E. Soto). (Right) A male Juan Fernandez Tit-tyrant (photo credit: Ingo J. Hahn).

Figura 2. (Izquierda) Detalle de un claro de bosque hecho por humanos que incluye las ramas apiladas en el suelo y el bosque nativo adyacente, Plazoleta del Yunque (Fotografía: Gerardo E. Soto). (Derecha) Cachudito de Juan Fernández macho (Fotografía: Ingo J. Hahn). 


\section{Capture Data}

Fourteen 10-m long and 2.6-m height mist-nets were randomly established in the study area in order to determine the microhabitat use pattern by tit-tyrants within forest habitat. All mist-nets were placed $1.5 \mathrm{~m}$ above the ground, a height that is consistent with the height at which tit-tyrant move (Hahn et al. 2009). Of these nets, 10 were located in native forest and 4 in forest gaps, these being separated by more than $100 \mathrm{~m}$ (Fig. 1). Mist netting stations were opened for $6 \mathrm{hrs}$ a day and checked every half hour for about 26 days during February and March 2011, totalizing a per-net effort (hours x net) of 156 hrs. All captured birds were ringed and then released. Bird abundance was estimated for each mist netting station by dividing the number of caught birds (without including recaptures) by the total number of hours per net.

\section{RADIO-TRACKING}

During March 2011, corresponding to the post-breeding season of tit-tyrants, a $9 \mathrm{~g}$ male tit-tyrant was caught in a mist-net and color-ringed as part of a long-term monitoring program (Fig. 2). Because of the threat status of this species, and considering that transmitters could induce mortality of small bird species, we tracked a single individual. A $0.6 \mathrm{~g}$ backpack-mounted transmitter was attached to this tit-tyrant using epoxy glue, which was later released ca. 20 min after its capture. Two telemetry sessions were conducted daily (once in the morning and another in the afternoon) every other day for a week, totaling six sessions. Each session involved a $40 \mathrm{~min}$ sampling period with bearings being recorded at $1 \mathrm{~min}$ interval in order to obtain a fine scale time series. During the last telemetry session we realized that the transmitter was detached due to no movement was recorded.

\section{Home Range}

Bearings were triangulated using LOCATE II (Nams 2000). We tested for "time to independence" (Swihart and Slade 1985) using the Schoener's (1981) index, which estimates the time interval on which data become temporally independent of each other, with values larger than 1 being considered as acceptable (Kenward 2001). Once fixes (estimated locations) were filtered for autocorrelation, we used them to determine a kernel home range for the male tit-tyrant. Two different bandwidths (i.e., smoothing parameters) were used to calculate the kernel: Least Squared Cross-Validation (LSCV) and Plug-in (Kertson and Marzluff 2010, and references therein). After fitting the kernel density function we selected the LSCV bandwidth because the Plug-in estimation resulted in an overestimation of the kernel area in one spatial axis. We used Animal Movement extension in ArcView 3.3 (Hooge \& Eichenlaub 1997) and the KernSmooth package in R 2.13.0 (Wand 2006; Wand and Jones 1995) for estimating LSCV and Plug-in bandwidths, respectively. We validated the resulting kernel home range by comparing its use distribution values (i.e., the amount of use at the location relative to the other locations in the home range) at locations where the individual was mist netted and the site where the transmitter was recovered with distribution values drawn from random locations. Additionally, georeferenced observations of the individual were graphically compared to the home range area.

\section{Habitat Selection}

We assessed micro-habitat selection at the population level using abundance estimates from mist netting capture data. Previously we determined that covariates were not correlated $(\mathrm{r}<0.5$, for all variables). We used linear regression models to test the effects of composite-based and distance-based variables. We used an informationtheoretic approach of model selection based in the Akaike's information criterion $(A I C)$ and Akaike weights to evaluate the support for competing a priori models explaining bird abundance. Our selection procedure involved all possible combinations of variables in the set of competing models. Competing models were ranked by their differences in AIC with the most parsimonious model (DAIC) and models with $\triangle \mathrm{AICc}$ values $\leq 2$ were considered to be strongly supported. We also computed the adjusted $R^{2}$ statistic that represents the proportion of variance explained by the model. Averaged coefficients with their adjusted standard errors, $p$-values and relative importance values were estimated from the best supported competing models containing each predictor variable (Burnham and Anderson 2002). Multimodel inference analyses were carried out using the MuMIn package (Barton 2010) of $R$ program (version 2.13.1; R Development Core Team 2011).

We examined third-order habitat selection (sensu Johnson 1980) of the tracked tit-tyrant by using a Resource Utilization Function (RUF model implemented from the ruf package in R 2.13.0; Marzluff et al. 2004). For this analysis the $99 \%$ kernel home range was rasterized at a cell size of $8 \mathrm{~m}$ corresponding to mean distance error of telemetry fixes. Thus, for each cell we calculated the utilization values rescaled from 0 to 99 (the heights of use distribution values which represent the strength of use of each spatial location) and micro-habitat covariates . A Matern covariance function was included in order to account for spatial autocorrelation between neighboring data points. We developed three model subsets including the independent and combined effects of composite-based and distance-based variables on the habitat use of the tit-tyrant. An information-theoretical approach based on the AIC (Akaike's Information Criterion) was used to evaluate the support for competing models (Burnham and Anderson 2002). 


\section{RESULTS}

From a total of 240 fixes, only 32 were used to calculate the Kernel home range of the male tit-tyrant (Fig. 1; Fig. 3). The rest of fixes were discharged due to the following reasons: 1 ) we removed the $5 \%$ harmonic mean outliers; 2) we removed fixes with large error distances; 3 ) the bootstrapping curve of the Schoener's index reached an asymptotic value of ca. 1.4 at a $4 \mathrm{~min}$ interval, hence fixes were sequentially removed each $4 \mathrm{~min}$ in order to get temporal independence.

The $99 \%$ home range size of the tit-tyrant was 0.56 ha, being located entirely within native forest in the vicinity of gaps. Native forest comprised the $81.3 \%$ of the home range area, with the rest of the area corresponding to forest gaps (Fig. 3). The kernel home range was successfully validated from independent observed locations (Fig. 3). The utilization values at the locations where the transmitter was recovered and where the individual was mist-netted were 36.2 and $41.3 \%$, respectively, whereas random locations had a mean utilization value of $21.6 \pm 3.4 \%$. In addition, all visual observations of the individual ( $\mathrm{n}=12$ points) fell within the home range.

Micro-habitat selection at the population level was explained mostly by distance-based variables. Only two candidate abundance models were supported by data $(\mathrm{DAIC}<2)$. The best supported model had as predictors the distance to Gunnera shrub and distance to exotic shrub (Table 1). Akaike weights indicated that such a model was about 2.3 times more likely than the second best model, which only included the distance to exotic shrub (Table 1). The two best models explained, respectively, 54 and 27 percent of the variance in abundance (Table 1). Abundance decreased with distance to Gunnera shrub and increased with distance to exotic shrub, with both coefficients being significant (Table 2). According to their importance values, distance to exotic shrub had a larger probability of being included in the best model than distance to Gunnera shrub (Table 2).

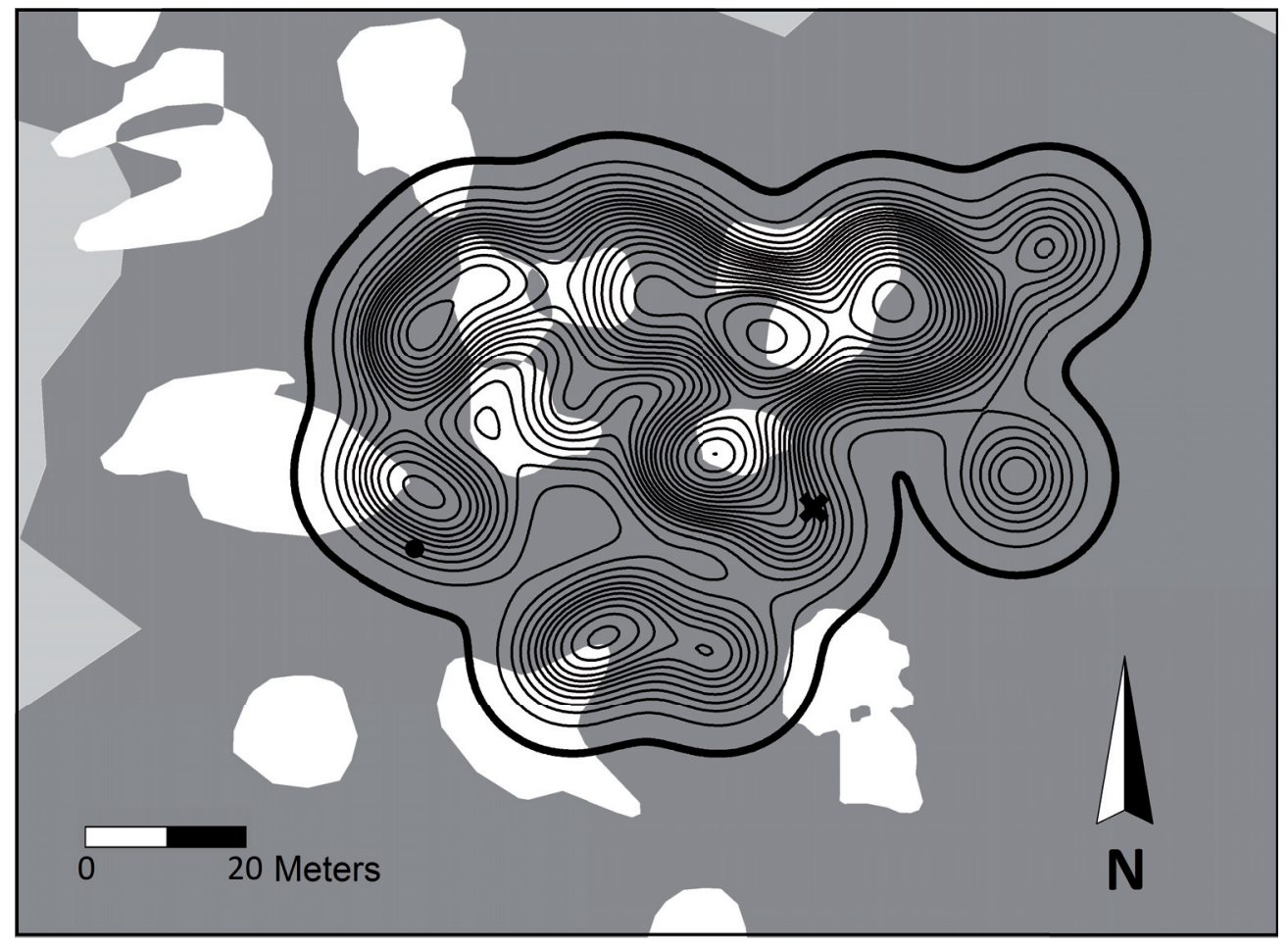

FIGURE 3. Kernel home range for the radio-tracked Juan Fernandez Tit-tyrant showing isopleths in increments of $5 \%$. The outer thick line represents the $99 \%$ kernel home range boundary. The point represents the location where transmitter was recovered whereas the cross is the mist-net where the tit-tyrant was recaptured two times.

Figura 3. Ámbito de hogar del Cachudito de Juan Fernández muestreado usando telemetría mostrando isopletas en incrementos de 5 \%. La línea gruesa exterior representa la frontera del ámbito de hogar. El punto representa el lugar donde el transmisor fue recuperado mientras que la cruz es la red en donde el Cachudito fue recapturado dos veces.. 
Distance-based and mixed models were the most parsimonious RUF models (i.e., DAIC $\leq 4$ ) indicating that micro-habitat use is dependent on both distance-based and composite-based variables (Table 3 ). In addition, the Akaike weights $(W)$ of these models indicated that the best distancebased model was only 1.6-fold more likely than the mixed model (Table 3). The composite-based forest gap variable affected negatively to resource utilization probabilities (Table 4). Utilization values also decreased significantly with increasing the distance from the forest gaps and Gunnera shrub, with the former standardized coefficient showing a stronger effect (Table 4).

TABLE 1. A priori candidate models explaining the micro-habitat selection pattern within the native forest for Juan Fernandez Tit-tyrant during the post-breeding season in Robinson Crusoe Island. Only models belonging to the $95 \%$ confidence set of candidate models are shown, with $\mathrm{k}$ representing the number of parameters in the model.

TABLA 1. Modelos candidatos que explican el patrón de selección del micro-hábitat dentro del bosque nativo para el Cachudito de Juan Fernández durante la temporada post reproductiva en la isla Robinson Crusoe. Se muestran solamente el conjunto de los mejores modelos que acumulan un 95\% del peso en AIC sobre el total de modelos, con $\mathrm{k}$ representando el número de variables del modelo.

\begin{tabular}{|c|c|c|c|c|c|}
\hline MOdel & $\mathrm{k}$ & AIC & DAIC & Weight & $\mathrm{R}^{2}$ \\
\hline Distance to Gunnera shrub + Distance to exotic shrub & 3 & 29.5 & 0.00 & 0.42 & 0.54 \\
\hline Distance to exotic shrub & 2 & 31.2 & 1.66 & 0.18 & 0.27 \\
\hline Gaps & 2 & 32.2 & 2.68 & 0.11 & 0.18 \\
\hline Gaps + Distance to Gunnera shrub & 3 & 32.7 & 3.24 & 0.08 & 0.37 \\
\hline Distance to Gunnera shrub & 2 & 33.0 & 3.54 & 0.07 & 0.00 \\
\hline Distance to Gaps & 2 & 33.0 & 3.55 & 0.07 & 0.00 \\
\hline Distance to Gaps + Distance to Gunnera shrub + Distance to exotic shrub & 4 & 35.1 & 5.61 & 0.03 & 0.56 \\
\hline Distance to Gaps + Distance to exotic shrub & 3 & 35.4 & 5.93 & 0.02 & 0.17 \\
\hline Gaps + Distance to Gunnera shrub + Distance to exotic shrub & 4 & 35.5 & 6.00 & 0.02 & 0.54 \\
\hline
\end{tabular}

TABLE 2. Model-averaged coefficients, standard errors (SE), p values and Importance values from models explaining the micro-habitat selection pattern within the native forest for Juan Fernandez Tit-tyrant during the post-breeding season in Robinson Crusoe Island (see TABLE 1).

TABLA 2. Coeficientes promediados de los modelos, error estándar (SE), valores de probabilidad (p) e Importancia de los modelos que explican el patrón de selección del micro-hábitat dentro del bosque nativo para el Cachudito de Juan Fernández durante la temporada post reproductiva en la isla Robinson Crusoe (ver TABLA 1).

\begin{tabular}{lllll}
\hline Variable & COEFficient & SE & $\mathrm{p}$ & IMPORTANCE \\
\hline Distance to exotic shrub & 0.04 & 0.02 & 0.049 & 1.00 \\
Distance to Gunnera shrub & -0.01 & 0.00 & 0.030 & 0.70 \\
\hline
\end{tabular}

TABLE 3. Selected Resource Utilization Functions (RUFs) for a Juan Fernandez Tit-tyrant during the post-breeding season in Robinson Crusoe Island.

TABLA 3. Funciones de Utilización de Recursos (RUFs) elegidas para un Cachudito de Juan Fernández durante la temporada post reproductiva en la isla Robinson Crusoe.

\begin{tabular}{|c|c|c|c|c|c|c|}
\hline Model & Covariates & Log-lik & p-value & AIC & $\triangle \mathrm{AIC}^{*}$ & $W$ \\
\hline Distance-based & Distance to Gunnera shrub + Distance to Gaps & -395.7 & $<0.001$ & 801.5 & 0.00 & 0.58 \\
\hline Mixed & Distance to Gunnera shrub + Distance to Gaps + Gaps & -395.2 & $<0.001$ & 802.4 & 0.91 & 0.37 \\
\hline Composite-based & Gaps & -399.2 & $<0.001$ & 806.5 & 4.95 & 0.05 \\
\hline
\end{tabular}

*Models with $\triangle \mathrm{AIC}<4$ were considered as parsimonious models. 
TABLE 4. Standardized RUF coefficients with their standard errors (SE) and p-values of the best Mixed RUF model for a Juan Fernandez Tit-tyrant (Table 3).

TABLA 4. Coeficientes estandarizados del RUF con su error estándar (SE) y valores de p del mejor modelo RUF mixto para un Cachudito de Juan Fernández (Tabla 3).

\begin{tabular}{llll}
\hline Coefficient & Value & $\mathrm{SE}$ & $\mathrm{p}$-value \\
\hline Distance to forest gaps & -8.9 & 0.15 & $<0.001$ \\
Distance to Gunnera shrub & -7.8 & 0.21 & $<0.001$ \\
Forest gaps & -1.0 & 0.05 & $<0.001$ \\
Intercept & 11.2 & 0.19 & $<0.001$ \\
\hline
\end{tabular}

\section{DISCUSSION}

The studied male Juan Fernandez Tit-tyrant established its home range exclusively in core native forest areas with presence of forest gaps. The preference of native forest by tit-tyrants has been demonstrated in previous studies (e.g., Hahn 2006; Hahn et al. 2005, 2011b). Such studies suggest that tit-tyrants maintain their preference for native forest in spite of their population decline trend (Hahn et al. 2006, 2011a). If this population decline is associated to habitat loss, then the preservation of the remnant native forest area has got priority in landscape planning.

The studied tit-tyrant showed a home-range size similar to that of birds with the same body size (Calder 1984). Bird density estimated from mist netting data was about $1.3 \mathrm{ind} /$ ha (i.e., 13 individuals captured in a 10 ha plot). The above density estimates are consistent with data collected between 1995 and 2009, which show a mean density of about $1.6 \mathrm{ind} /$ ha in native forest (Hahn 2006, 2011b). Although the home range estimate was based on data taken during a relatively short time period, our mist net sampling data and visual observations demonstrated that the male tit-tyrant held the same territory during the post-breeding season. These findings, together with the fact that during the breeding season the tit-tyrants are concentrated in native forest areas, corroborate that tit-tyrants tend to prefer native forest as a primary habitat for most of the year.

Tit-tyrants showed strong micro-habitat preferences both, at the population level (i.e., mist-netting abundance) and within their home ranges (i.e., utilization values). Although the tracked male tit-tyrant avoided using forest gaps, the abundance of tit-tyrants and the utilization probabilities declined with increasing distance to these human created gaps.

This implies that tit-tyrants not only could have perceived the gaps as an unsuitable micro-habitat, but also they could respond to a habitat quality gradient from the forest edge to the interior. Since this species should have evolved in an environment dominated by native forests in a geographically isolated area, its foraging behavior should have a high degree of specialization in the use of forest resources.

Natural heterogeneity in micro habitat conditions also affected the habitat selection pattern of the tit-tyrant. Our results evidenced a positive effect of the proximity to sites dominated by Gunnera peltata. It is probable that the humid conditions that characterize such moist sites, located along seasonal or permanent small watersheds, spread into the adjacent upland native forest. Thus, local gradients in humidity conditions, may be responsible for the larger use probability by tit-tyrants of the sites located close to Gunnera shrub formations (e.g., Hahn et al. 2010).

The micro-habitat use pattern showed by tit-tyrants could contribute not only to understand the particular ecology of this species but also to design efficient guidelines for species conservation at different spatial levels. At the habitat stand level the preservation of native remnants in Robinson Crusoe should be a priority since tit-tyrants fundamentally use this habitat type for nesting and foraging (Hahn et al. 2006, 2011a). At the micro-habitat level, however, some specific considerations should be adopted. First, the artificial gap formation as a result of the exotic shrub eradication should not be considered as a detrimental disturbance for tit-tyrants because of their positive effects on micro-habitat use. Second, Gunnera formations should be conserved as buffer areas acting as food sources for tit-tyrants. Third, the connectivity between Gunnera shrub formations and upland native forest should be increased in order to maintain moist native ecotones which are rich in invertebrates. Although our results are consistent in showing how habitat preferences vary within home-ranges, more detailed work will be necessary to assess the effects of micro-habitat scale variability, such as topography and exposure.

Our findings demonstrate the importance of micro-habitat on the distribution of tit-tyrants in this protected area. Since our conclusions data were drawn from only one radiotracked individual, they could not necessarily represent the expected habitat selection pattern at the entire population. However, results from regression models of abundance and 
RUF models of telemetry data were consistent in showing the same habitat selection pattern of tit-tyrants (e.g., Table 2, Table 4). Moreover, the radio-tracked individual was a territorial male who did not changed its home range during the studied season. Regarding the above reasons, it is highly probable that the habitat selection pattern displayed by the studied individual is representative to the set of reproductive individuals within the population. In order to have more complete information about individuals of different age, gender and social status, we suggest the need to expand our analysis in order to obtain robust conclusions for species conservation. In addition, monitoring program studies are urgently necessary given the sharp decline in population size that this species has suffered in the last decades (Hahn et al. 2011a). This information could be used for implementing habitat management programs at the landscape level, not only for tit-tyrants but also for other endangered endemic species.

\section{ACKNOWLEDGEMENTS}

The Chilean CONAF granted us our island and national park work permits. We are grateful to M. Galvez, J. Reyes, J. Mesa, G. Gonzalez, C. Diaz, E. Gonzalez and all park rangers, with special thanks to Silvia Moreno and Ivan Leiva for field assistance and hospitality. The study was supported by the Humboldt Foundation (AvH).

\section{REFERENCES}

Aebischer, N.J., Robertson, P.A. \& Kenward, R.E. 1993. Compositional analysis of habitat use from animal radiotracking data. Ecology 74:1313-1325.

BARTON K. 2010. MuMIn: multi-model inference, R package version 0.13.17.

Burnham, K.P. \& Anderson, D.R. 2002. Model Selection and Multimodel Inference: A Practical Information-Theoretic Approach. Second edition. Springer, New York. 488 pp.

Calder, W.A. 1984. Size, Function, and Life History. Harvard University Press, Cambridge. 431 pp.

Cofré, H. 1999. Patrones de rareza de las aves del bosque Templado de Chile: implicancias para su conservación. Boletín Chileno de Ornitología 6:8-16.

Conner, L.M., Smith, M.D. \& Burger, L.W. 2003. A comparison of distance-based and classification-based analysis of habitat use. Ecology 84:526-531.

Cuevas, J.G., \& Van Leersum, G. 2001. Project "Conservation, restoration, and development of the Juan Fernández islands", Chile. Revista Chilena de Historia Natural 74:899-910.

Fordham, D. \& BRook, B. 2010. Why tropical island endemics are acutely susceptible to global change. Biodiversity and Conservation 19:329-342.

HAHN, I. 2006. First reproductive records and nest sites of the endemic Juan Fernández Tit-tyrant Anairetes fernandezianus (Philippi 1857) (Aves: Tyrannidae) from Robinson Crusoe Island, Chile. Zoologische Abhandlungen 55:177-190.

Hahn, I., Römer, U. \& Schlatter, R. 2005. Distribution, habitat use, and abundance patterns of land bird communities on the Juan Fernández Islands, Chile. Ornitología Neotropical 16:371-385.

Hahn, I., Römer, U. \& Schlatter, R. 2006. Population numbers and status of land birds of the Juan Fernández Archipelago, Chile. Senckenbergiana biologica 86:109-125.

Hahn, I., Römer, U., Vergara, P. \& Walter H. 2009. Biogeography, diversity, and conservation of the birds of the Juan Fernández Islands, Chile. Vertebrate Zoology 59:103-114.

Hahn, I., Vergara, P. \& Römer, U. 2010. Vegetation structure affects bird community composition in an island ecosystem: the role of nativity and introduction. Geo-Öko 31:1-10.

Hahn, I., Vergara, P. \& Römer, U. 2011A. Habitat selection and population trends in terrestrial bird species of Robinson Crusoe Island: habitat generalists versus forest specialists. Biodiversity and Conservation DOI: 10.1007/s10531-0110109-x

Hahn, I., Vergara, P. \& Römer, U. 2011B. Importance of nest attributes in the conservation of endemic birds of the Juan Fernández Archipelago, Chile. Bird Conservation International DOI: 10.1017/S0959270911000050

Hooge, P. \& Eichenlaub, P. 1997. Animal movement extension to ArcView ver 1.1. Alaska Science Center-Biological Science Office, Anchorage, AK, USA. US Geological Survey.

IUCN. 2011. The Red List of threatened species v. 2011.1, Gland. http://www.iucnredlist.org. Accessed 30 August 2011.

Johnson, D.H. 1980. The comparison of usage and availability measurements for evaluating resource preference. Ecology 61:65-71.

Kenward, R.E. 2001. A manual for wildlife radio tagging. Academic Press, London. 311 pp.

Kertson, B.N. \& Marzluff, J.M. 2010. Improving studies of resource selection by understanding resource use. Environmental Conservation 38:18-27.

KRISTAN, W.B.III. 2006. Sources and expectations for hierarchical structure in bird-habitat associations. The Condor 108:512.

Loehle, C. \& Eschenbach, W. 2012. Historical bird and terrestrial mammal extinction rates and causes. Diversity and Distributions 18(1):84-91 DOI: $10.1111 / \mathrm{j} .1472-$ 4642.2011.00856.x

Marzluff, J., Millspaugh, J., Hurvitz, P. \& Handcock, M. 2004. Relating resources to a probabilistic measure of space use: forest fragments and Steller's jays. Ecology 85:1411-1427.

Nams, V. 2000. Locate II user's guide. Pacer Computer Software, Tatamagouche. $76 \mathrm{pp}$.

Owens, I.P.F. \& BennetT, P.M. 2000. Ecological basis of extinction risk in birds: habitat loss versus human persecution and introduced predators. Proceedings of the National Academy of Sciences of the United States of America 97:12144-12148.

RICCI, M. 2006. Conservation status and ex-situ cultivation efforts of endemic flora of the Juan Fernandez Archipelago. Biodiversity and Conservation 15:3111-3130.

Roy, M.S., Torres-Mura, J.C. \& Hertel, F. 1999. Molecular 
Micro-habitat selection of Juan Fernandez Tit-tyrant: GERARdo Soto ET AL.

phylogeny and evolutionary history of the tit-tyrants (Aves: Tyrannidae). Molecular Phylogenetics and Evolution 11(1):67-76.

Schoener, T.W. 1981. An empirically based estimate of home range. Theoretical Population Biology 20:281-325.

SkottsberG, C. 1956. The natural history of Juan Fernandez and Easter Islands. 3 volumes. Almquist Wiksells Boktryckeri, Sweden. 1920 pp.

Stuessy, T.F., Ono, M. (Eds). 1998. Evolution and Speciation of Island Plants. Cambridge University Press, Cambridge. $358 \mathrm{pp}$.

Swihart, R.K. \& Slade, N.A. 1985. Testing for independence of observations in animal movements. Ecology 66:1176-1184.
Vargas, R., Reif, A. \& Faundez, M.J. 2011. Los bosques de la isla Robinson Crusoe, Chile: hotspot de endemismo en peligro. Bosque 32(2):155-164.

Vergara, P.M. \& Armesto, J.J. 2009. Responses of Chilean forest birds to anthropogenic habitat fragmentation across spatial scales. Landscape Ecology 24:25-38.

WAND, M. 2006. KernSmooth: functions for kernel smoothing for Wand and Jones (1995). R package version 2.22-19. R port by Brian Ripley [www document]. URL http://cran.rproject.org/web/packages/KernSmooth/KernSmooth.pdf

Wand, M.P. \& Jones, M.C. 1995. Kernel Smoothing. Chapman and Hall, London. 212 pp.

Recibido: 10.01 .12

Aceptado: 25.03 .13 